\title{
NOTES AND DESCRIPTIONS OF ORIENTAL EESTROPSYCHINAE (TRICHOPTERA)
}

\author{
BY NATHAN BANKS \\ Museum of Comparative Zoology
}

There are a number of species in this group in the Orient, although for many years it was the custom to call every specimen of Polymorphanisus, $P$. nigricornis, and every Estropsyche as $E$. vitrina.

Having a considerable number of specimens from India, it is seen that each is fairly constant in structural characters, both of body and wings.

\section{Polymorphanisus}

The species of this genus fall into two sections; one with the fourth fork sharply acute at base and extending well back on the median cell and with the fore wing not especially broad; to this belongs nigricornis and some allied forms; the other section has broad, rather short wings, and the fork four is broad at base and goes back but little, if at all, on the median cell; to this group belong indicus, ocularis, astictus. The females of the first group from Asia known to me can be separated as follows:

1. Head swollen in front in a rounded lobe, mesoscutellum with two black stripes, discal cell very short tumidus

Head not prominently swollen in front

2. Fringe of mid tarsi blackish, antennæ black ............ 3

Fringe of mid tarsi paler ..................................... 4

3. A dark spot on mesoscutellum, discal cell short, front legs pale unipunctus

No spot on mesoscutellum, discal cell about one half as long as median cell, front tibiæ and often femora blackish nigricornis 
4. Legs yellowish, fringe of mid tarsi yellowish; antennæ dark only at joints; front tibiæ with only a dark dot at tips flavipes

Legs pale, not distinctly yellowish, fringe of mid legs silvery, outer half of front tibiæ black; fore wings rather broader than usual hainanensis

$P$. taonicus Navas from South China I do not know.

\section{Polymorphanisus nigricornis Walk.}

Walker says the antennæ and the fringe on legs black. This form has the front tibiæ more or less dark, and often the femora also. The discal cell is about one-half as long as the median cell, fork one longer than its pedicel, fork four well back on median cell, but not halfway to the crossvein, latter before middle of cell, cross-vein from median fork to cubitus is straight and about twice its length before base of median cell. There are no distinct marks on the mesonotum, nor does Walker mention any.

Many specimens from Shimoga, Mysore, India.

Polymorphanisus unipunctus Bks. Fig. 4

From Suifu (Graham) and Chin Chi Shan (Gaines Liu), both Szechuan; fork one is very short as well as the discal cell.

\section{Polymorphanisus flavipes sp. nov.}

Pale greenish, rarely a trace of dark each side on the mesonotum, abdomen dark, ventral segments more or less tipped with pale; antennæ pale, sometimes somewhat darkened toward tips, the joints narrowly black at tips, basal joint behind with a black streak; legs yellowish, front and mid tibiæ with dark dot at tips, fringe of mid legs plainly yellowish.

Wings greenish, with green veins; discal cell rather short, not one-half of median cell; fork one longer than pedicel, fork four back on median cell about width of median, not halfway to the cross-vein which is much before the middle of cell; cross-vein from median fork to cubitus 
about two and one-half times its length before median cell; venation of hind wings much as in nigricornis.

Length of fore wing 20 to $23 \mathrm{~mm}$.

From Shimoga, and Bhadravati, Mysore, India, in May, June, August, September, and October (Susai Nathan). Two specimens with rather more yellowish wings have a very distinct black spot each side on the mesonotum, and the fourth apical cell is more narrow than in the other specimens. Type M. C. Z. no. 23467.

Polymorphanisus tumidus sp. nov. Figs. 11, 12

Pale greenish, abdomen dull black, mesoscutellum with two short black stripes, antennæ greenish, black mark at the joinings, legs pale greenish, front pair unmarked, mid legs with the tibiæ and tarsi yellowish, a black spot at tips of tibiæ and tarsal joints, the fringe brownish yellow; front of head with a great, smooth, rounded swelling in front.

Fore wings greenish, veins green; discal cell very small, only about one-fourth as long as median cell, and fully as high as long; fork one about three times as long as the pedicel, fork four well back on median cell, but not halfway to the cross-vein, which is much before the middle of cell; cross-vein from median fork to cubitus fully three times its length before median cell; venation of hind wing much as usual.

Length of fore wing 19 to $20 \mathrm{~mm}$.

From Shimoga, Mysore, India, 15 to 28 April (Susai Nathan coll.). Remarkable for the peculiar head. Type M. C. Z. no. 23468.

From the larger Malayan islands there are at least three species, and doubtless more.

\section{Polymorphanisus semperi Brauer}

In some specimens there are two faint dark marks on the mesoscutellum, and also present more plainly in all three males I have seen. All of my specimens are from Luzon.

\section{Polymorphanisus fuscus Ulmer}

Two females from Telang, Borneo (Grabowsky) have the black spots near base of fore wings; the mesoscutellum is 
almost wholly black, and two narrowly separated black spots in front on the margin of the mesonotum.

Polymorphanisus scutellatus sp. nov. Fig. 9

Pale yellowish to greenish; no marks on head nor legs; antennæ pale, narrowly dark at tips of joints; mesoscutellum with two black spots; abdomen dull black. Wings greenish, veins green, the veins about discal cell and several apical veins in upper part are bordered with yellowish, much as in $P$. semperi.

Fore wings moderately slender, about as nigricornis, not at all sinuate on outer margin ; discal cell is four-sided, fork two rather deeply indenting the anastomosis, the discal cell not nearly one-half as long as the median cell, cross-vein from lower side of discal to the median is obliquely backward; median cell very long, not nearly as wide as discal, fork four extending back on the median cell about one-half the width of cell; cross-vein from median cell to cubitus before middle of cell ; fork one not nearly as long as its pedicel.

Venation of hind wing much as in semperi, except that fork five is only one half as long, shorter than in any other species noted.

Length of fore wing 15 to $18 \mathrm{~mm}$.

From Baram River district, Sarawak, Borneo (H. W. Smith 1912) ; others marked Sarawak, and one from Hagen collection, Duson Tinoc, Borneo (Grabowsky). Type M.C.Z. no. 23472.

Differs from semperi by shape of fore wing and many points of venation.

A specimen from Buitenzorg, Java (T. Barbour) and one from Medan, Sumatra (G. Fairchild) have the same venation but the mesoscutellum is almost wholly black, and quite possibly represent another species.

\section{Estropsyche vitrina Hagen Figs. 5, 14}

Both of Hagen's males have the median cell longer than figured by Ulmer (Selys Monog. Trich. (2) fig. 21) for his Celebes or Sumatra specimen. Fork four is also more geniculate at base than he figures; in the hind wing the 
venation is much as he figures but forks two and three are well separated at base.

E. palingenia Brauer from the Philippines is distinct, and probably also some other island forms. In the female of palingenia, the discal cell is not so wide as in the male, and is nearly as far from the radius as its own width, and fork two is not short-pedicellate, but only much narrowed at base. I figure (Fig. 2,) the appendages of a male from Mt. Makeling, Luzon (U.S.N.M. coll.) .

I have from India another species, possibly the one referred to vitrina by Martynov (Rec. Ind. Mus. XXXVII, p. 93). I give a figure of the fore wing of the type of $E$. vitrina.

\section{Estropsyche hageni sp. nov. Fig. 6}

This has the same general appearance as Hagen's species, but is smaller; fore wing $12 \mathrm{~mm}$., Hagen's type $15 \mathrm{~mm}$. The median cell is about a fourth shorter than vitrina, with a very short margin on the cubitus, the inner side less sinuate, the fork four fully as much curved at base. In the hind wing fork one is very short, otherwise like vitrina. In the mid legs the second tarsal joint is nearly one-half of the first, in vitrina scarcely more than one-third, and the membranous margin is of a more even width.

The genitalia have the claspers of about the same proportions as in vitrina, but the tip of the penis in vitrina has a projection below, which is lacking in hageni; from above the superior plate is slightly projecting in the middle.

From Shimoga, Mysore, India, 21 July (Susai Nathan). Type M.C.Z. no. 23469.

Amphipsyche apicalis sp. nov. Figs. 1, 3, 8, 15

o Pale yellowish, face silvery on the sides, thorax and apical part of the abdomen rather darker yellow; legs pale whitish, unmarked; antennæ pale, joints narrowly dark at tips; palpi long, apical part rather dark.

Fore wing sparsely clothed with yellowish hair, more yellowish along anal margin, a brighter yellowish cloud before anastomosis, another one transversely beyond anastomosis, and the apical part broadly yellow, in the apical 
part of fork one is a rounded black spot; hind wings pale whitish. Fore wings rather long, tip broadly rounded. Venation much as in $A$. nirvana (indica), the radius strongly sinuate, radial sector nearly straight, median cell more slender than usual, a minute cell at base of fork two which is pedicellate; hind wings much as in other species, the cubital fork slender, as in A. tricalcarata. Spurs 1, 4, 4, the subapical pair of hind legs rather small and close together, but plainly two. Male genitalia above much as in $A$. distincta, but from beneath the claspers have the basal part very slender, not at all enlarged as in distincta; the penis has a large hump beyond middle, further from the tip than in $A$. nirvana, and the tip of penis, seen from below (or above) is slender and bifid.

Fore wings $13 \mathrm{~mm}$. long.

From Shimoga, Mysore, India, 10 April (Susai Nathan). Type M.C.Z. no. 22677.

Two females from Coimbatore, have fork two pedicellate, but no cell at base, a small dark cloud near upper end of anastomosis, hind tibia with but one preapical spur, may be the female of this species.

\section{Amphipsyche distincta Mart.}

A species agreeing in genitalia, head and thorax markings and in venation is common in Mysore, India. Martynov does not mention the front femora which in these specimens are plainly blackish, and show very prominently from in front. The wings of fresh specimens are very plainly greenish. The female also has these black front femora, is smaller, the wings scarcely at all green, but the abdomen is green (at least when fresh). The mesonotum usually has a dark stripe each side, and scutellum largely dark; the brown on head as in male, The mid tibia are broadened as usual, there is a distinct, but sometimes minute, subbasal spur, and the apical spurs are simple, but inner much shorter than outer; hind legs with only the apical spurs. The venation is similar to that of the male, except that the radius, of course, is but little curved near tip, and the cross-vein from median cell to lower median vein is usually much nearer to the middle of cell, radial sector straight. The fore wing is 
but $6.5 \mathrm{~mm}$. long, male $9 \mathrm{~mm}$. Many from Shimoga, Mysore (Susai Nathan).

Amphipsyche magna sp. nov. Figs. 13, 16, 17

Head and thorax pale yellowish, with more pale hair than usual; abdomen brown; antennæ pale, tips of joints dark; mesonotum with a brown stripe on each side toward wingbase, and a spot each side on the posterior part of mesoscutellum; metanotum with a brown spot each side in front; legs pale yellowish, unmarked; fore wings pale yellowish with yellowish veins (green alive?), the subcosta and radius faintly bordered with yellowish; hind wings very pale.

In fore wings the venation is typical; about seven faint costal cross-veins; the subcosta before tip bends down and then up, and the radius close by follows it, beyond which the radius makes a deep bend; fork one about equal to its pedicel; the median cell broad and rather short, upper side in an even curve.

Legs slender, femora fringed, spurs $1,4,2$, one of the subbasal pair of mid leg is curved. From above the genitalia show a broad, deeply divided superior plate, the long arms slightly divergent, and almost swollen before tip; the claspers are long and very slender, the apical part straight, tapering, and hardly one-half of the basal part; the tip of the penis from behind appears round, the two dark, pointed processes standing upright, some distance apart.

Fore wing $19 \mathrm{~mm}$. long.

One from Del Carmen, Philippine Islands (Uichanco), 15 Nov. Type M.C.Z. no. 23471.

Amphipsyche delicata sp. nov. Figs. 7, 10

A small, pale yellowish gray species with unmarked wings. Head pale yellowish; antennæ pale, faintly, narrowly annulate with dark; palpi pale, fully as long as usual; legs pale, front tibia with a minute dark spot at tip; fore wings pale yellowish gray, unmarked, the stigmal area rather more yellowish than elsewhere. Venation much as usual, but the median cell extends much beyond the anastomosis, rather more so than in $A$. minima, the median cell is not so much widened in the middle as in A. minima, 
and its upper border is plainly thickened ; fork one is scarcely longer than pedicel; one costal cross-vein fairly distinct and sometimes a second shows, fork two sessile.

Mid leg of female with tibia less swollen than in most of the larger species; spurs $0,4,4$, the preapical pair of hind legs very small, and one of the apical pair is much longer than the other.

Length of fore wing 7 to $7.5 \mathrm{~mm}$.

From Chung Kon, 18 July; Dome Mt. 13 July, both on Hainan Island, and Kit Tau, South Kiangsi, China, 20 June (Gressitt). Type M.C.Z. no. 23470.

It differs from $A$. minima in not having fork two pedicellate, in lacking the faint brown band over anastomosis, and in shape of the median cell; from the equally small $A$. distincta it differs in not having front femora and tibiæ darkened, in shape of the median cell, etc.

\section{Explanation of Plates I AND II.}

Fig. 1. Amphipsyche apicalis, fore wing.

2. Estropsyche palingenia, genitalia below.

3. Amphipsyche apicalis, genitalia above, and penis from side and above.

4. Polymorphanisus unipunctus, part of fore wing.

5. Estropsyche vitrina, tip of penis.

6. Estropsyche hageni, tip of penis.

7. Amphipsyche delicata, part of fore wing and hind leg.

8. Amphipsyche apicalis, genitalia below.

9. Polymorphanisus scutellatus, part of fore wing.

10. Amphipsyche delicata, part of hind wing.

11. Polymorphanisus tumidus, part of fore wing.

12. Polymorphanisus tumidus, head from side.

13. Amphipsyche magna, tip of penis and clasper.

14. Estropsyche vitrina, median cell of fore wing of male.

15. Amphipsyche apicalis, genitalia, side.

16. Amphipsyche magna, superior plate, above.

17. Amphipsyche magna, fore wing of male. 


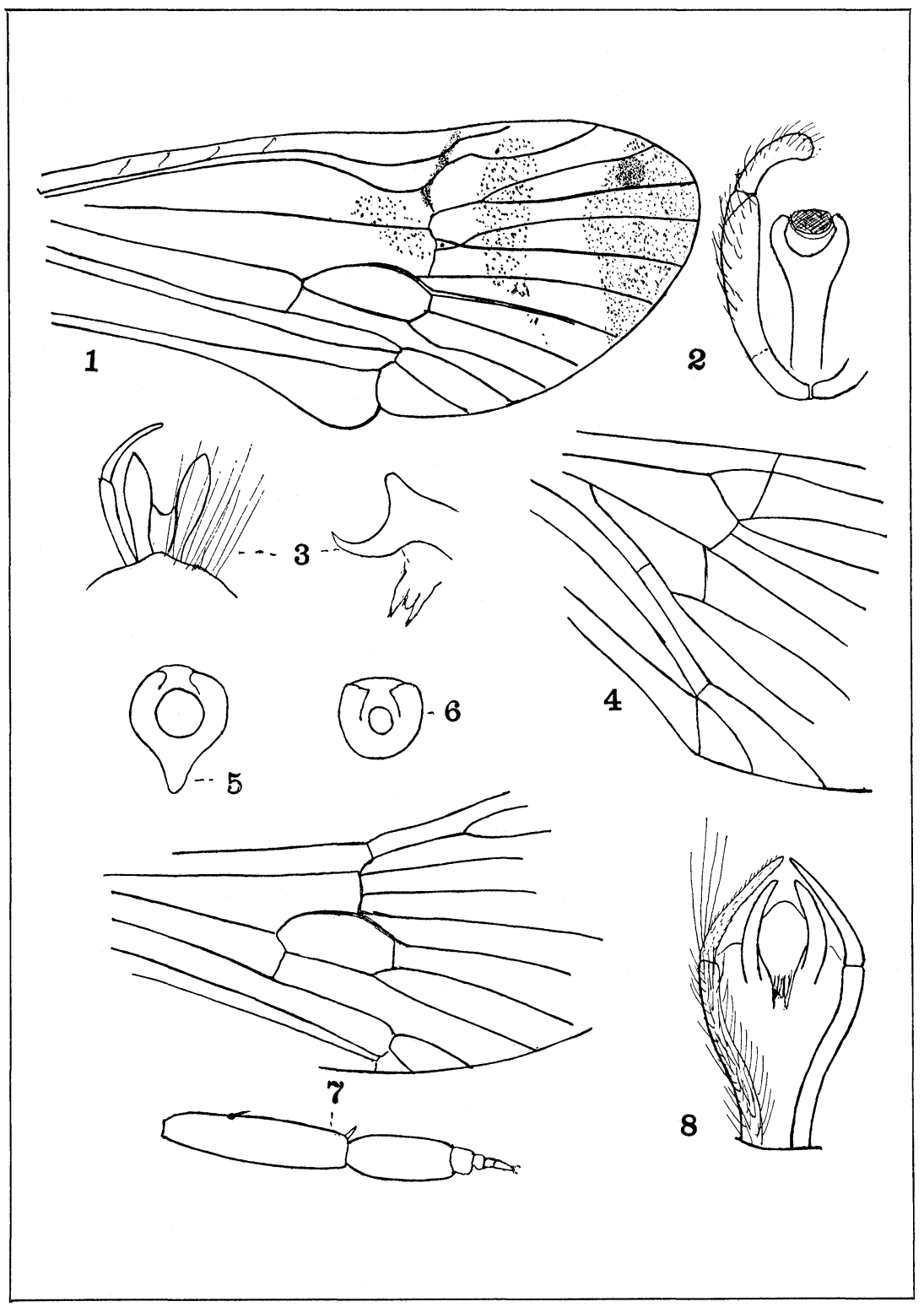

Banks - Oriental Estropsychinæ 


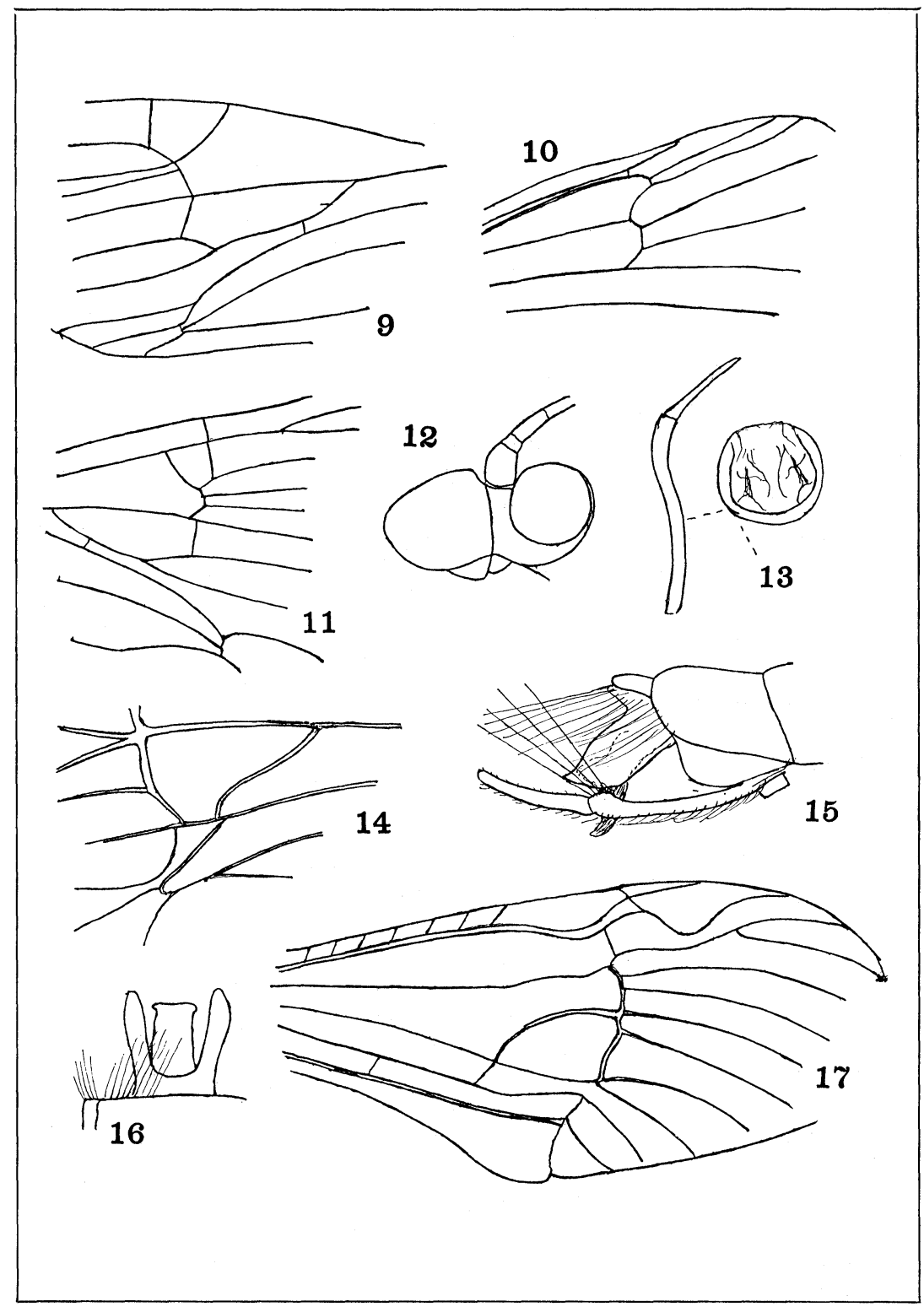

Banks - Oriental Estropsychinæ 

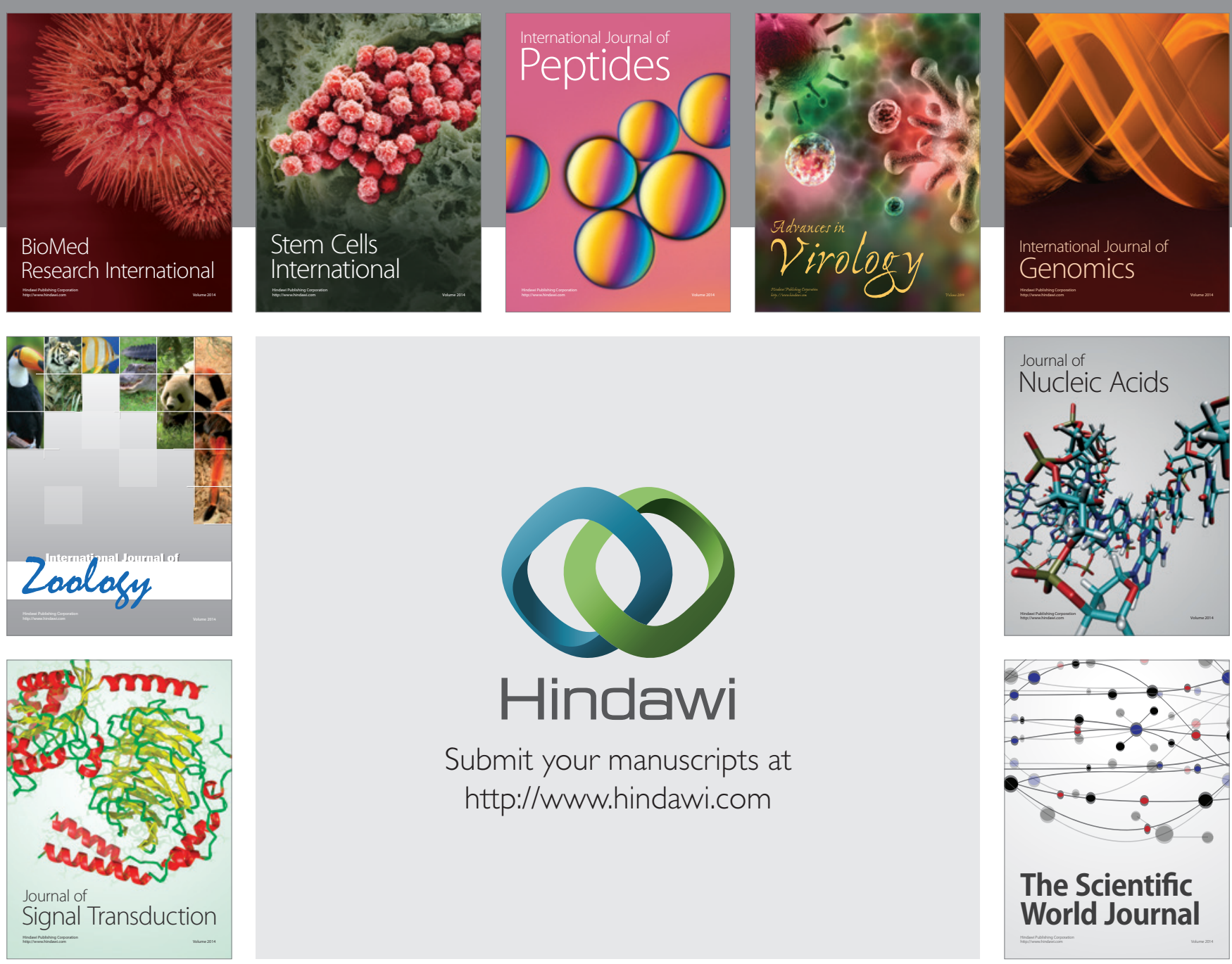

Submit your manuscripts at

http://www.hindawi.com
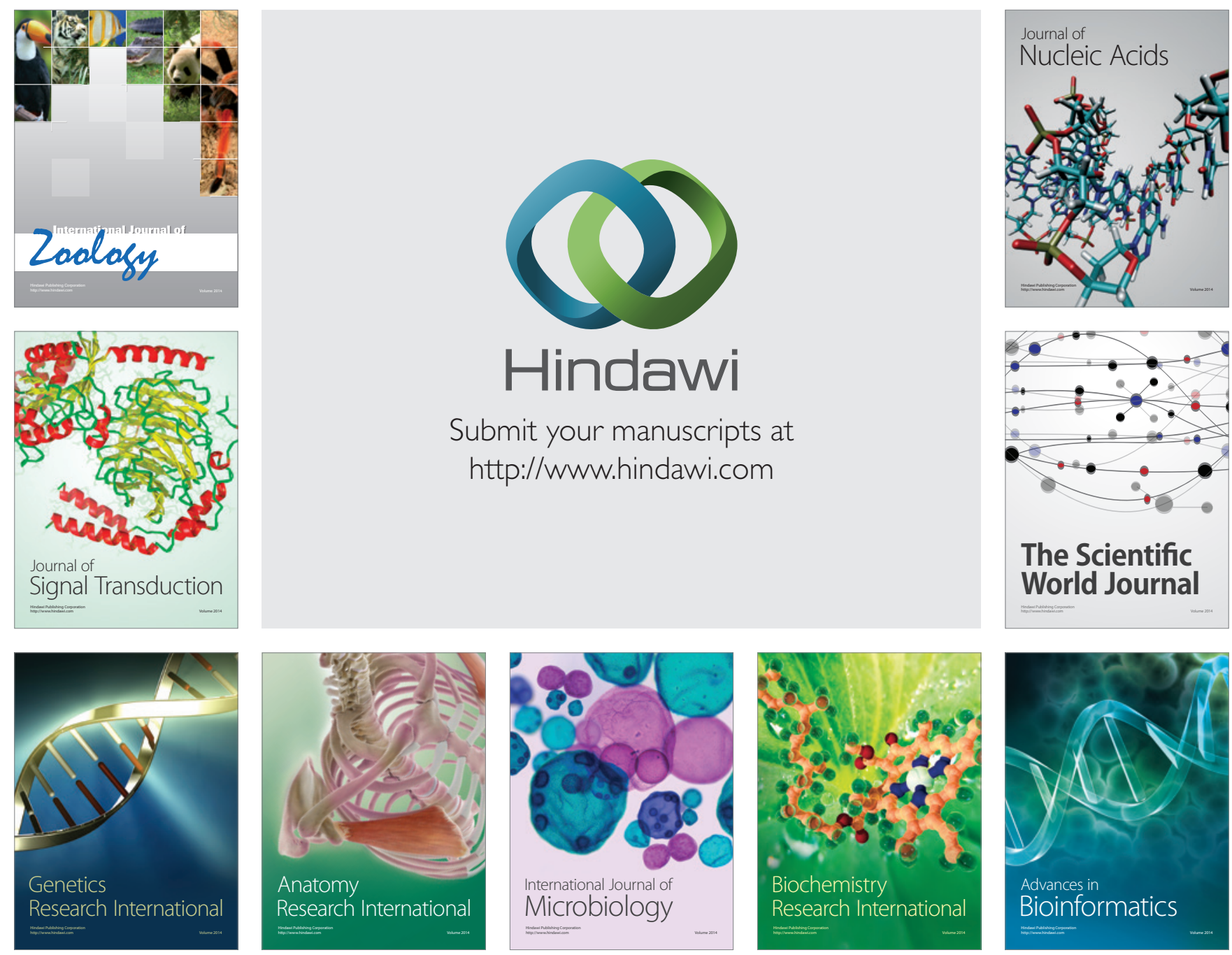

The Scientific World Journal
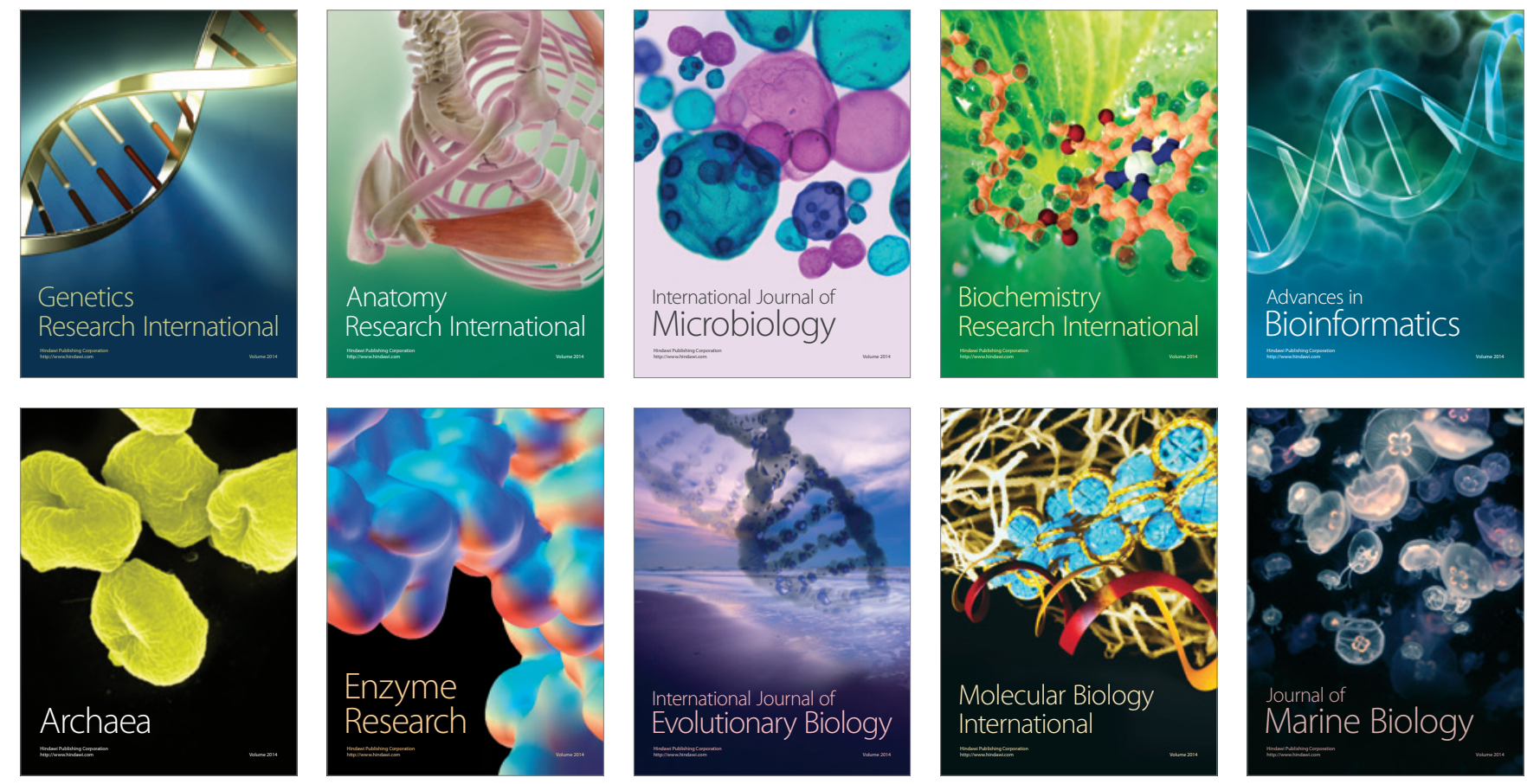